\title{
ANALISIS TURNOVER TERHADAP KINERJA KEUANGAN DENGAN REVENUE SEBAGAI VARIABEL MODERASI (STUDI PADA PT.MADUKISMO YOGYAKARTA TBK)
}

\author{
SUBARJO \\ Prodi Manajemen Universitas Mercu Buana Yogyakarta \\ Email: subarjo71@gmail.com \\ FITRI WULAN SARI \\ Prodi Manajemen Universitas Mercu Buana Yogyakarta \\ Email: wulan.sari@yahoo.com
}

\begin{abstract}
Abstrak
Penelitian ini dilakukan untuk menganalisis perputaran terhadap kinerja keuangan dengan revenue sebagai variabel moderasi pada perusahaan PT.Madukismo Yogyakarta Tbk periode tahun 2004-2013 serta untuk mengetahui pengaruh perputaran piutang dan perputaran persediaan pada perusahaan PT.Madukismo Yogyakarta Tbk. Rasio keuangan yang digunakan sebagai variabel adalah Receivable Turnover (RT), Inventory Turnover (IT), dan Net Profit Margin (NPM). Populasi penelitian ini adalah periode atau waktu dari pabrik gula PT.Madukismo Yogyakarta yang berdiri atau beroperasi sampai sekarang yaitu dari tahun 1958 sampai dengan tahun 2015 kurang lebih 57 tahun, dengan sampel yang digunakan sebanyak 9 tahun data yang diambil dengan teknik purposive sampling. Hasil analisis dengan uji regresi berganda yang telah dilakukan dalam penelitian ini dapat disimpulkan bahwa Receivable Turnover dan Inventory Turnover tidak berpengaruh signifikan terhadap kinerja keuangan. Sedangkan untuk hasil analisis dengan uji regresi moderasi revenue memperkuat pengaruh Receivable Turnover terhadap kinerja keuangan.
\end{abstract}

Kata kunci: Receivable Turnover, Inventory Turnover, Moderasi, Kinerja Keuangan.

\section{PENDAHULUAN}

PT.Madukismo adalah salah satu pabrik gula dan alkohol/spirtus terbesar di daerah Istimewa Yogyakarta. Gula merupakan kebutuhan yang sangat diperlukan bagi masyarakat luas, di indonesia kebutuhan gula masih kurang

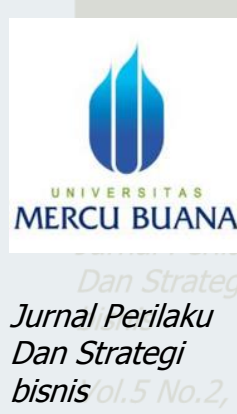

Vol.5 No.2, 2017

Hal. $201-220$ sehingga indonesia masih mengimpor dari negara lain. Persaingan yang semakin ketat akan mempengaruhi semua bidang usaha, baik usaha jasa, produksi maupun perdagangan. Dewasa ini ukuran keberhasilan itu kebanyakan dinilai dari aspek finansial perusahaan atau tingkat penjualan, walaupun sekarang juga masih banyak yang menggunakan ukuran tersebut. Maju dan suksesnya pabrik tidak tergantung pada satu orang atau satu lini saja melainkan beberapa pihak yang sudah dikoordinasi dan mengetahui tugas dan tanggung jawab mereka masing - masing demi suksesnya perusahaan. Perseroan 
terbatas merupakan badan usaha dan besarnya modal perseroan tercantum dalam anggaran dasar. Kekayaan perusahaan terpisah dari kekayaan pribadi pemilik perusahaan sehingga memiliki harta kekayaan sendiri. Setiap orang dapat memiliki lebih dari satu saham yang menjadi bukti pemilikan perusahaan. Pemilik saham mempunyai tanggungjawab yang terbatas, yaitu sebanyak saham yang dimiliki.

Apabila hutang perusahaan melebihi kekayaan perusahaan, maka kelebihan hutang tersebut tidak menjadi tanggungjawab para pemegang saham. Apabila perusahaan mendapat keuntungan maka keuntungan tersebut dibagikan sesuai dengan ketentuan yang ditetapkan. Pemilik saham akan memperoleh bagian keuntungan yang disebut dividen yang besarnya tergantung pada besar kecilnya keuntungan yang diperoleh perseroan terbatas. Perkembangan ekonomi dunia yang semakin pesat dan kondisi bisnis yang tidak menentu disaat ini mengakibatkan permasalahan yang dihadapi oleh bidang usaha semakin kompleks dan dinamis. Masalah yang selalu dihadapi oleh perusahaan adalah masalah keuangan. Untuk itu perencanaan bisnis yang benar-benar matang sangat diperlukan untuk memperoleh return yang sesuai dengan yang diharapkan. Analisa kinerja keuangan termasuk hal yang harus diperhatikan dalam perencanaan bisnis yang baik. Sektor manufaktur merupakan sektor yang tidak hanya menekan pada padat teknologi atau modal, akan tetapi juga padat karya, dengan demikian nilai tambah ekonomi bagi perekonomian nasional yang diberikan oleh sektor ini tidak hanya menghasilkan devisa yang disebabkan karena produk-produknya yang diekspor keluar negri, akan tetapi juga adanya nilai tambah ekonomi dalam penyerapan jumlah tenaga kerja yang dapat mengurangi pengangguran yang akhirnya akan meningkatkan pendapatan masyarakat baik langsung maupun tidak langsung. Nilai tambah lain yang diberikan adalah meningkatkan peluang penerimaan negara seperti devisa, karena produk-produk yang dihasilkan tidak saja untuk memenuhi kebutuhan pasar dalam negri, akan tetapi juga untuk pasar luar negri. Sektor ini pasarnya juga sudah jelas karena sebagian besar perusahaan dalam sektor ini sudah mempunyai hubungan istimewa dengan pihak lain dalam pemasaran produk dan pemasokan kebutuhan bahan baku.

Nilai tambah lain adalah pengurangan jumlah penggangguran, hal ini dengan jumlah penduduk yang cukup besar maka ini akan merupakan peluang pasar yang cukup besar untuk menyerap hasil-hasil produksinya. Dengan demikian nilai tambah bagi perekonomian nasional tidak saja diterima oleh perusahaan dan pemerintah, akan tetapi juga oleh masyarakat itu sendiri. Perusahaan manufaktur dapat memberikan peluang bagi masyarakat untuk mengembangkan usaha home industri dengan membuat usaha-usaha yang menjadi rekanan bagi perusahaan manufaktur yang sudah besar. Adanya usaha-usaha rekanan ini akan memberikan nilai tambah ekonomi yang tidak kecil bagi perekonomian nasional. Kesuksesan suatu perusahaan dapat diukur dari suksesnya memproduksi barang dan jasa sehingga barang dan jasa yang diproduksi pada akhirnya akan dapat meningkatkan hasil operasi perusahaan tersebut. Terdapat banyak kriteria yang dapat digunakan sebagai variabel penilaian hasil operasi perusahaan diantaranya perubahan volume dan omset penjualan, tingkat laba kotor dan laba bersih. Akan tetapi kriteria tersebut tidak terlepas dari besar kecilnya jumlah investasi dan sumber permodalan yang digunakan untuk merealisasikan laba tersebut. 
Menurut Harnanto (2001:302), bahwa struktur permodalan perusahaan berbeda disebabkan oleh perbedaan karakteristik diantara tiap-tiap sumber atau jenis permodalan tersebut. Perbedaan karakteristik diantara tiap-tiap jenis atau sumber permodalan itu, secara umum mempunyai akibat atau pengaruh pada dua aspek penting didalam kehidupan setiap perusahaan, yaitu : 1) terhadap kemampuannya untuk menghasilkan laba, dan 2) terhadap kemampuan perusahaan untuk membayar kembali hutang / kewajiban-kewajiban jangka panjangnya. Hal ini berarti bahwa jumlah komposisi aktiva dan sumber permodalan yang digunakan (Modal Sendiri dan Hutang Jangka Panjang) merupakan beberapa faktor yang dapat mempengaruhi prestasi perusahaan yang salah satu indikatornya adalah perolehan pendapatan/laba. Berdasarkan pada pernyataan diatas, maka dipahami bahwa pengukuran kinerja keuangan perlu mempertimbangkan adanya tahapan siklus kehidupan bisnis yaitu pertumbuhan (growth), bertahan (sustain), dan memanen (harvest). Pada setiap tahapan siklus kehidupan tersebut memiliki sasaran dan nilai investasi yang berbeda, sehingga penekanan pengukuran yang dilakukan akan berbeda pula.

Ada 4 metode yang digunakan dalam mengukur kinerja keuangan perusahaan selama ini, yatu: Metode Rasio Keuangan yang merupakan alat yang digunakan untuk menilai kinerja perusahaan yang menekankan operasi keuangan, Metode Economic Value Added (EVA) yang digunakan dalam menilai kinerja perusahaan yang memfokuskan pada penerapan nilai dan hanya bisa menilai proses dalam periode satu tahun, Metode Balanced Scorecard (BSC) merupakan alat untuk mengukur kinerja perusahaan dengan menyeimbangkan faktor - faktor keuangan dan non keuangan dari suatu perusahaan, dan Metode Radar yang merupakan alat untuk menilai kinerja pada perusahaan yang merupakan modifikasi atau penyempurnaan dari metode - metode sebelumnya. Dalam penelitian yang akan dilakukan pada PT.Madukismo Yogyakarta peneliti menggunakan Rasio Aktivitas yang terdiri atas Receivable Turnover dan Inventory Turnover. Receivable Turnover merupakan tingkat perputaran piutang yang menunjukkan cepatnya dana terikat dalam piutang atau dengan kata lain cepatnya piutang dilunasi oleh debitur. Sedangkan Inventory Turnover merupakan rata-rata persediaan dengan menjumlahkan nilai persediaan awal tahun dengan nilai persediaan akhir tahun dan dibagi dengan 2. Sedangkan untuk mengukur kinerja keuangan peneliti menggunakan rasio keuangan yaitu profitabilitas yang terdiri dari Net Profit Margin. Net Profit Margin merupakan ukuran keuntungan dengan membandingkan antara laba setelah bunga dan pajak dibandingkan dengan penjualan atau dengan kata lain, rasio pendapatan bersih perusahaan.

\section{PENELITIAN TERDAHULU}

Penelitian terdahulu dilakukan oleh Tjandera (2006) yang meneliti faktor-faktorfaktor Turnover yang mempengaruhi kinerja keuangan perusahaan real estate dan property go public. Variabel yang digunakan Working Capital Turnover (WCT), Receivable Turnover (RC), Debt to Equity Ratio (DER), Net Profit Margin (NPM), Inventory Turnover (ITO), dan Total Asset Turnover (TATO). Hasil penelitian menyimpulkan bahwa variabel Debt to Equity Ratio (DER), Net Profiit Margin (NPM), dan Total Asset Turnover (TATO) berpengaruh terhadap kinerja keuangan. Sedangkan variabel Working Capital Turnover (WCT), Receivable Turnover (RTO) dan Inventory Turnover (ITO) tidak berpengaruh terhadap kinerja keuangan. Asiah (2011) melakukan penelitian tentang analisis faktor - faktor Turnover yang mempengaruhi kinerja keuangan perusahaan industri tekstil yang terdaftar 
pada bursa efek Indonesia. Variabel yang digunakan Receivable Turnover (RTO), Average Collections Periods, Inventory Turnover (ITO), Average Day's Inventories, Total Assets Turnover (TATO), Debt Ratio (DR) dan Current Ratio (CR). Hasil penelitian menunjukkan Inventory Turnover (ITO), Average Day's Inventories, Total Assets Turnover (TATO), Debt Ratio $(D R)$ dan Current Ratio $(C R)$ secara parsil berpengaruh terhadap kinerja keuangan, sedangkan variabel Receivable Turnover (RTO) dan Average Collections Periods tidak berpengaruh terhadap kinerja keuangan.

Selanjutnya Hernawati (2007) melakukan penelitian menggunakan variabel Working Capital Turnover (WCT), Current Ratio (CR) dan Debt to Total Asset (DTA) yang menguji pengaruhnya terhadap kinerja keuangan pada perusahaan barang konsumsi go public di bursa efek Jakarta pada tahun 2002 - 2005. Hasil penelitian menyimpulkan bahwa secara simultan variabel Working Capital Turnover (WCT), Current Ratio (CR) dan Debt to Total Asset (DTA) berpengaruh terhadap kinerja keuangan, sedangkan secara parsial hanya variabel Working Capital Turnover (WCT) yang berpengaruh terhadap kinerja keuangan. Selanjutnya Hernawati (2007) melakukan penelitian menggunakan variabel Working Capital Turnover (WCT), Current Ratio (CR) dan Debt to Total Asset (DTA) yang menguji pengaruhnya terhadap kinerja keuangan pada perusahaan barang konsumsi go public di bursa efek Jakarta pada tahun 2002 - 2005. Hasil penelitian menyimpulkan bahwa secara simultan variabel Working Capital Turnover (WCT), Current Ratio (CR) dan Debt to Total Asset (DTA) berpengaruh terhadap kinerja keuangan, sedangkan secara parsial hanya variabel Working Capital Turnover (WCT) yang berpengaruh terhadap kinerja keuangan.

\section{RUMUSAN MASALAH}

Berdasarkan latar belakang yang telah diuraikan diatas, maka dapat diterapkan pokok masalah yang dikemukakan dalam penelitian ini adalah:

1. Apakah ada pengaruh perputaran piutang terhadap kinerja keuangan pada PT.Madukismo Yogyakarta ?

2. Apakah ada pengaruh perputaran persediaan terhadap kinerja keuangan pada PT.Madukismo Yogyakarta ?

3. Apakah revenue memoderasi perputaran piutang terhadap kinerja keuangan pada PT.Madukismo Yogyakarta?

\section{TEORI DAN PENGEMBANGAN HIPOTESIS}

Kinerja keuangan merupakan sesuatu yang dihasilkan oleh suatu perusahaan dalam periode tertentu dengan mengacu pada standar yang ditetapkan. Kinerja perusahaan hendaknya merupakan hasil yang dapat diukur dan menggambarkan kondisi empirik suatu perusahaan dari berbagai ukuran yang disepakati. Untuk mengetahui kinerja yang dicapai maka dilakukan penilaian kinerja. Kata penilaian sering diartikan dengan kata assesment. Sedangkan kinerja perusahaan merupakan sesuatu yang dihasilkan oleh suatu perusahaan dalam periode tertentu dengan mengacu pada standar yang ditetapkan. Dengan demikian penilaian kinerja perusahaan (Companies Performance Assesment) mengandung makna suatu proses atau sistem penilaian mengenai pelaksanaan kemampuan kerja suatu perusahaan (organisasi) berdasarkan standar tertentu (Kaplan dan Norton, 2003).

Martono dan Harjito (2008:52) berpendapat bahwa kinerja keuangan suatu perusahaan sangat bermanfaat bagi berbagai pihak (stakeholders) seperti investor, kreditur, 
analis, konsultan keuangan, pialang, pemerintah, dan pihak manajemen sendiri. Wahyudin (2008:48) bahwa : "Kinerja keuangan merupakan sesuatu yang dihasilkan oleh suatu organisasi dalam periode tertentu dengan mengacu pada standar yang ditetapkan." Sawir (2005 : 1) mengemukakan bahwa analisis kinerja keuangan adalah suatu aktivitas atau kegiatan untuk mengetahui kondisi keuangan perusahaan serta mempengaruhi kemampuan perusahaan untuk berkembang, membayar deviden dan menghindari kebangkrutan. Tujuan penilaian kinerja adalah untuk memotivasi personel mencapai sasaran organisasi dan mematuhi standar perilaku yang telah ditetapkan sebelumnya, agar membuahkan tindakan dan hasil yang diinginkan oleh organisasi. Standar perilaku dapat berupa kebijakan manajemen atau rencana formal yang dituangkan dalam rencana strategik, program dan anggaran organisasi. Penilaian kinerja juga digunakan untuk menekan perilaku yang tidak semestinya diinginkan, melalui umpan balik hasil kinerja pada waktunya serta penghargaan, baik yang bersifat intrinsik maupun ekstrinsik.

Laporan keuangan ialah neraca dan perhitungan rugi laba serta segala keteranganketerangan yang dimuat dalam lampiran-lampirannya antara lain laporan sumber dan penggunaan dana-dana. laporan keuangan merupakan hasil dari sebuah sistem informasi akuntansi, sebagai media komunikasi bagi pemakai informasi untuk mengetahui posisi keuangan perusahaan baik dari sisi likuiditas maupun profitabilitasnya, serta perubahan yang signifikan terhadap sumber daya yang dimiliki. Laporan keuangan dipersiapkan atau dibuat dengan maksud untuk memberikan gambaran atau laporan kemajuan (Progres Report) secara periodik yang dilakukan pihak manajemen yang bersangkutan. Jadi laporan keuangan adalah bersifat historis serta menyeluruh dan sebagai suatu Progres Report laporan keuangan terdiri dari data-data yang merupakan hasil dari suatu kombinasi antara : fakta yang telah dicatat (recorded fact), prinsip dan kebiasaan-kebiasaan didalam akuntansi (accounting convertion and postulate), pendapat pribadi (personal judgement).

Analisis rasio keuangan digunakan untuk membuat keputusan dibidang keuangan, dengan menganalisis laporan keuangan perusahaan yang terdiri atas Neraca, Laporan Rugi Laba, dan Laporan Arus Kas. Analisis yang sering digunakan adalah analisis rasio keuangan. Analisis rasio keuangan merupakan bentuk atau cara yang umum digunakan untuk mengevaluasi keadaan financial perusahaan dimasa lalu sekarang dan masa yang akan datang. Analisis rasio keuangan merupakan salah satu teknik untuk mendeteksi kondisi keuangan perusahaan dengan membandingkan pos daftar keuangan dengan pos yang lain untuk mendapatkan indikasi atau kesimpulan tentang salah satu atau beberapa aspek kondisi keuangan. Rasio keuangan dapat digunakan untuk memprediksi tingkat pertumbuhan laba perusahaan dimasa yang akan datang. Rasio keuangan bermanfaat bagi pihak manajemen untuk perencanaan dan pengevaluasian prestasi kinerja (performance). Perusahaannya bila dibandingkan dengan rata - rata industri, sedangkan bagi para kreditor dapat digunakan untuk memperkirakan potensi resiko yang akan dihadapi berkaitan dengan adanya jaminan kelangsungan pembayaran bunga dan pengembalian pokok pinjaman. Analisis rasio juga bermanfaat bagi investor dalam mengevaluasi nilai saham dan adanya jaminan atas keamanan dana yang ditanamkan pada suatu perusahaan. Analisis laporan keuangan juga dimanfaatkan oleh Banker untuk membuat keputusan memberi atau menolak kredit. 
Pada umumnya tujuan perusahaan adalah untuk memperoleh laba dengan menggunakan sumber ekonomi yang dimiliki. Perolehan laba merupakan indikator untuk menilai prestasi manajer dalam mengelola perusahaannya, sehingga wajar bila manajer dikatakan berhasil bila manajer tersebut dapat meningkatkan laba perusahaan. Pengertian laba yang terdapat dalam laporan rugi laba yang digunakan dalam perhitungan rasio keuangan adalah sebagai berikut (Simangunsong, $1995: 80$ ) :

a. Laba kotor adalah laba sebelum dikurangi dengan biaya - biaya usaha (penghasilan bersih dikurangi harga pokok pembelian).

b. Laba bersih adalah laba kotor setelah dikurangi dengan semua biaya - biaya usaha (biaya penjualan ditambah biaya administrasi umum).

c. Laba sebelum pajak adalah laba bersih hasil usaha setelah ditambah atau dikurangi rugi atau laba yang berasal dari luar usaha pokok.

d. Laba setelah pajak adalah laba sebelum pajak dikurangi pajak

Dari perbandingan rugi laba dua periode atau lebih dapat diambil kesimpulan (Simangunsong, $1995: 80$ ) :

a. Apabila besarnya laba bertambah atau kerugian berkurang hal ini menunjukkan keadaan perusahaan bertambah baik (perkembangan perusahaan positif).

b. Apabila besarnya laba berkurang atau kerugian bertambah hal ini menunjukkan keadaan perusahaan justru mengalami kemunduran (perkembangan perusahaan negatif).

Konsep perilaku laba yang berkaitan dengan keputusan para investor dan kreditor. Adapun konsep perilaku menurut Chariri dan Ghozali adalah:

a. Laba Sebagai Pengukuran Efisiensi.

Efisiensi adalah kemampuan menghasilkan output secara maksimal relatif terhadap sejumlah Resourse tertentu, atau suatu output yang konstan dengan pemakaian Resourse yang minimal atau kombinasi dari Resourse secara optimal untuk memenuhi permintaan tertentu dengan harga tertentu sehingga menghasilkan maksimal return bagi pemilik perusahaan.

b. Laba Sebagai Alat Prediksi

FASB (Statesment of Financial Accounting Concep : 1) menyatakan bahwa: para investor kreditor dan pemilik lain - lainnya ingin menilai prospek arus masuk kas bersih perusahaan tetapi mereka saling menggunakan laba untuk membantu mereka mengevaluasi daya beli (earning power), meramalkan laba dimasa yang akan datang. Atau menafsir resiko berinvestasi atau memberikan pinjaman kepada perusahaan. Bagi suatu perusahaan peramalan laba dianggap lebih relevan meramalkan harga dimasa yang akan datang.

Hubungan antara rasio keuangan dan laba perusahaan, Salah satu karakteristik kualitatif yang harus dimilikiinformasi akuntansi agar tujuan pelaporan keuangan dapat tercapai adalah kemampuan memprediksi (Zainuddin dan Hartono, 1999 : 68). Rasio keuangan diduga mampu membedakan perubahan laba (laba naik atau turun), untuk menguji kemampuan memprediksi perubahan laba dimasa mendatang dapat menggunakan rasio keuangan diambil dari informasi yang terdapat didalam laporan keuangan. Laba sebagai suatu pengukuran kinerja dan bagian dari laporan keuangan perusahaan, merefleksikan telah terjadi proses peningkatan atau penurunan ekuitas dari berbagai sumber transaksi kecuali transaksi dengan pemegang saham dalam periode tertentu. Konsep laba memasukkan hampir seluruh kejadian yang tercakup dalam pendapatan bersih 
dengan penekanan pada periode sekarang, sehingga prediksi perubahan laba dapat diteliti dengan menggunakan rasio keuangan (Ekawati, dkk, 2003 : 254).

Penerapan sistem penjualan secara kredit yang dilakukan perusahaan merupakan salah satu usaha perusahaan dalam rangka meningkatkan volume penjualan. Penjualan kredit tidak segera menghasilkan penerimaan kas, tetapi menimbulkan apa yang disebut dengan piutang, sehingga dengan kata lain piutang timbul karena perusahaan menerapkan sistem penjualan secara kredit.

Dalam berbagai referensi piutang sering juga diartikan sebagai bentuk klaim yang ditujukan kepada pihak lain sebagai hasil dari transaksi untuk tujuan akuntansi sebagaimana definisi yang dikemukakan oleh simon (1973) yang dikutip oleh manulang $(2005,34)$ sebagai berikut:

"The term receivable is applicable to all claims against other, wheter are claims for money, for goods, or for serving, for accounting purpose, however the term is employed is narrower sense to designate claims that are expected to be settled by the receipt of money". Dari pengertian diatas dapat disimpulkan bahwa piutang antara lain merupakan semua tuntutan terhadap langganan baik berbentuk perkiraan uang, barang maupun jasa dan segala bentuk perkiraan seperti transaksi. Penjualan secara kredit menimbulkan hak bagi perusahaan yang melakukan penagihan pada langganannya, dimana hal itu ditentukan oleh persyaratan yang telah disepakati bersama pada saat melakukan transaksi.

Adapun faktor-faktor yang mempengaruhi besar kecilnya dana yang diinvestasikan dalam piutang, menurut Riyanto (2001, 85-87) sebgaai berikut:

a. Volume Penjualan Kredit

Semakin besar proporsi penjualan kredit dari keseluruhan penjualan akan memperbesar jumlah investasi dalam piutang. Dengan demikian, makin besar volume penjualan kredit setiap tahunnya berarti bahwa perusahaan itu harus menyediakan investasi yang lebih besar lagi dalam piutang. Makin besar jumlah piutang berarti makin besar resiko tidak tertagihnya piutang, tetapi bersamaan dengan itu juga memperbesar profitabilitasnya.

b. Syarat Pembayaran Penjualan Kredit

Syarat pembayaran penjualan kredit dapat bersifat ketat atau lunak. Apabila perusahaan menetapkan syarat pembayaran yang ketat, berarti perusahaan lebih mengutamakan keselamatan kredit dari pada pertimbangan profitabilitasnya. Syarat pembayaran lebih ketat misalnya dalam bentuk batas waktu pembayaran yang pendek, pembebanan bunga yang berat pada pembayaran piutang yang terlambat.

c. Ketentuan Tentang Pembatasan Kredit

Dalam penjualan kredit, perusahaan dapat menetapkan batas maksimal kredit yang diberikan kepada para langganannya. Makin tinggi batas maksimal kredit yang ditetapkan bagi masing-masing langganan, berarti makin besar pula dana yang diinvestasikan dalam piutang. Demikian pula ketentuan mengenai siapa yang dapat diberi kredit. Makin selektif para langganan yang dapat diberi kredit, akan memperkecil jumlah investasi dalam piutang. Ketentuan dapat bersifat kuantitatif berupa batas maksimum kredit, dan dapat juga bersifat kualitatif berupa ketentuan mengenai siapa yang dapat diberi kredit.

Adapun faktor-faktor yang mempengaruhi volume penjualan menurut Kotler (2000 : 55) antara lain :

1. Harga Jual 
Faktor harga jual merupakan hal-hal yang sangat penting dan mempengaruhi penjualan atas barang atau jasa yang dihasilkan. Apakah barang atau jasa yang ditawarkan oleh perusahaan dapat dijangkau oleh konsumen sasaran.

2. Produk

Produk salah satu faktor yang mempengaruhi tingkat volume penjualan sebagai barang atau jasa yang ditawarkan oleh perusahaan apakah sesuai dengan tingkat kebutuhan para konsumen.

3. Biaya promosi

Biaya promosi adalah aktivitas-aktivitas sebuah perusahaan yang dirancang untuk memberikan informasi-informasi membujuk pihak lain tentang perusahaan yang bersangkutan dan barang-barang serta jasa-jasa yang ditawarkan.

4. Saluran distribusi

Merupakan aktivitas perusahaan untuk menyampaikan dana dan menyalurkan barang yang ditawarkan oleh perusahaan kepada konsumen yang diujinya.

5. Mutu

Mutu dan kualitas barang merupakan salah satu faktor yang mempengaruhi volume penjualan. Dengan mutu yang baik, maka konsumen akan tetap loyal terhadap produk dari perusahaan tersebut, begitu pula sebaliknya apabila mutu produk yang ditawarkan tidak bagus maka konsumen akan berpaling kepada produk lain.

Untuk menilai kondisi keuangan dan prestasi perusahaan, analisis keuangan memerlukan beberapa tolok ukur. Tolok ukur yang sering dipakai adalah rasio atau indeks, yang menghubungkan dua data keuangan yang satu dengan yang lainnya. Menurut Munawir $(2004,79)$ berdasarkan sumber analisis rasio keuangan dapat dibedakan atas:

a. Perbandingan Internal (internal comparison), yaitu membandingkan rasio pada saat ini dengan rasio pada masa lalu dan masa akan datang dalam perusahaan yang sama.

b. Perbandingan eksternal (external comparison) dan sumber-sumber rasio industri, yang membandingkan rasio perusahaan dengan perusahaan-perusahaan sejenis atau dengan rata-rata industri pada saat yang sama.

Menurut Bambang Riyanto (2003:329) Rasio Keuangan adalah ukuran yang digunakan dalam interprestasi dan analisis laporan finansial suatu perusahaan. Pengertian rasio itu sebenarnya hanyalah alat yang dinyatakan dalam arithmatical terms yang dapat digunakan untuk menjelaskan hubungan antara dua macam data finansial.

(Riyanto,2008) menyatakan bahwa Rasio Keuangan digunakan untuk memperlihatkan hubungan antara item-item pada laporan keuangan (neraca dan laporan laba rugi).

Pengertian analisis rasio keuangan menurut Weston (2005:225) adalah analisis rasio keuangan memberikan kerangka hubungan antara pos - pos neraca dan perhitungan laba rugi, memungkinkan seseorang menelusuri sejarah suatu perusahaan dan menilai posisi keuangannya saat ini, serta memungkinkan bagi manajer keuangan memperkirakan reaksi kreditur atau investor terhadap keadaan keuangan perusaahaan dan demikian dapat mencari cara - cara yang tepat untuk mendapatkan dana.

Suatu rasio tidak memiliki arti dalam dirinya sendiri, melainkan harus diperbandingkan dengan rasio yang lain agar rasio tersebut menjadi lebih sempurna dan untuk melakukan analisis ini dapat dilakukan dengan cara membandingkan prestasi suatu periode dengan periode sebelumnya sehingga diketahui adanya kecenderungan selama periode tertentu, 
selain itu dapat pula dilakukan dengan membandingkan dengan perusahaan sejenis dalam industri itu sehingga dapat diketahui bagaimana keuangan dalam industri tersebut.

Rasio Aktivitas yaitu rasio yang dimaksudkan untuk mengukur sampai seberapa besar efektivitas perusahaan dalam menggunakan sumber-sumber dananya. Rata-rata piutang didapat dari piutang awal tahun ditahun ditambah dengan akhir tahun dibagi dengan 2 . Rasio ini terbagi menjadi Receivable Turnover dan Inventory Turnover.

\section{Receivable Turnover}

Rasio ini merupakan perbandingan antara penjualan dengan piutang. Rasio perputaran ini digunakan untuk mengukur berapa lama penagihan piutang selama satu periode atau berapa kali dana yang tertanam dalam piutang ini berputar dalam satu periode. Semakin tinggi rasio menunjukkan bahwa modal kerja yang ditanamkan dalam piutang semakin rendah (bandingkan dengan rasio sebelumnya) dan tentunya kondisi ini bagi perusahaan semakin baik. Sebaliknya jika semakin rendah maka ada Over Invesment dalam piutang. Rumus yang digunakan adalah sebagai berikut:

\section{Inventory Turnover}

$$
\text { receivable turnover }=\frac{\text { penjualan kredit }}{\text { rata }- \text { rata piutang }}
$$

Rasio ini merupakan perbandingan antara penjualan dengan persediaan. Rasio perputaran ini digunakan untuk mengukur berapa kali dana yang ditanam dalam inventory ini berputar dalam satu periode. Rasio ini dikenal dengan nama rasio perputaran persediaan (Inventory Turnover). Rasio ini juga menunjukkan berapa kali jumlah barang persediaan diganti dalam satu tahun. Semakin kecil rasio ini maka semakin jelek, demikian pula sebaliknya. Rumus yang digunakan adalah sebagai berikut:

$$
\text { inventory turn over }=\frac{\text { harga pokok penjualan }}{\text { rata }- \text { rata persediaan }} \times 100 \%
$$

Rasio profitabilitas merupakan rasio untuk menilai kemampuan perusahaan dalam mencari keuntungan. Rasio ini juga memberikan ukuran tingkat efektifitas manajemen suatu perusahaan

\section{a. Net Profit Margin}

Margin keuntungan (Net Profit Margin) adalah untuk menunjukkan berapa besar persentase pendapatan bersih yang diperoleh dari setiap penjualan. Net Profit Margin digunakan untuk mengukur keuntungan netto atau laba bersih per rupiah penjualan. Semakin besar angka yang dihasilkan, menunjukkan kinerja yang semakin baik. Rumus yang digunakan adalah sebagai berikut:

$$
\text { net profit margin }=\frac{\text { laba setelah pajak }}{\text { penjualan }} \times 100 \%
$$

Menurut Schiffan (2005: 118), volume penjualan adalah tingkat penjualan yang diperoleh perusahaan untuk periode tertentu dalam satuan (unit/total/rupiah).

Istilah volume penjualan telah mengalami perubahan - perubahan selama beberapa tahun. Pada mulanya, para pengusaha menggunakan istilah tersebut untuk menunjukkan pengarahan tenaga penjualan atau disebut juga manajemen penjualan, kemudian istilah tersebut diartikan secara lebih luas lagi dengan penjualan dari seluruh kegiatan pemasaran, 
distribusi fisik, penetapan harga jual dan perencanaan produk tetapi sekarang istilah itu sudah dibedakan dengan menunjukkan kegiatan pemasaran menjual produknya.

Bagi setiap perusahaan tujuan yang hendak dicapai adalah memaksimumkan profit disamping perusahaan ingin tetap berkembang. Realisasi dari pada tujuan ini adalah melalui volume penjualan yang mantap karena masalah penjualan merupakan kunci dari sukses tidaknya suatu perusahaan. Dalam kegiatan marketing kenaikan volume penjualan merupakan ukuran efisiensi, meskipun tidak setiap kenaikan volume penjualan diikuti dengan kenaikan laba. Pengertian dari volume penjualan adalah jumlah dari kegiatan penjualan suatu produk atau jasa yang dihasilkan oleh perusahaan dalam suatu ukuran waktu tertentu.

Adapun pengembangan hipotesis dalam penelitian ini terbagi menjadi tiga (3) yaitu, pertama Receivable Turnover berpengaruh terhadap kinerja keuangan (aktivitas), kedua Inventory Turnover berpengaruh secara parsial terhadap kinerja keuangan (aktivitas), ketiga Revenue memperkuat pengaruh Receivable Turnover pada kinerja keuangan.

1. Receivable Turnover berpengaruh terhadap kinerja keuangan (aktivitas).

Penerimaan perusahaan merupakan bagian dari hal yang paling penting dalam siklus usaha. Makin besar penerimaan akan menciptakan laba yang makin besar, cateris paribus. Dengan makin besarnya laba perusahaan akan mendorong kinerja perusahaan yang makin tinggi. Sehingga hipotesis yang diajukan dalam penelitian ini adalah:

$\mathrm{H}_{1}$ : Diduga Receivable Turnover berpengaruh terhadap kinerja keuangan (aktivitas).

2. Inventory Turnover berpengaruh terhadap kinerja keuangan (aktivitas).

Inventory atau persediaan barang sebagai elemen utama dari modal kerja merupakan aktiva yang selalu dalam keadaan berputar, dimana secara terus menerus mengalami perubahan. Turnover menunjukkan berapa kali jumlah persediaan barang dagangan diganti dalam satu tahun (dijual dan diganti). Tingkat perputaran persediaan mengukur perusahaan dalam memutar barang dagangannya, dan menunjukkan hubungan antara barang yang diperlukan untuk mengimbangi tingkat penjualan yang ditentukan. Semakin sering barang dagangannya dijual dan diganti, maka kinerja suatu perusahaan tersebut semakin baik. Sehingga hipotesis yang diajukan dalam penelitian ini adalah:

$\mathrm{H}_{2}$ : Diduga Inventory Turnover berpengaruh terhadap kinerja keuangan (aktivitas

3. Revenue memperkuat pengaruh Receivable Turnover pada kinerja keuangan.

Volume penjualan merupakan jumlah total yang dihasilkan dari kegiatan penjualan barang. Semakin besar jumlah penjualan yang dihasilkan oleh perusahaan, semakin besar kemungkinan laba yang akan dihasilkan perusahaan. Oleh karena itu volume penjualan merupakan salah satu hal penting yang harus dievaluasi untuk kemungkinan perusahaan agar tidak rugi. Jadi volume penjualan yang menguntungkan harus menjadi tujuan utama perusahaan dan bukannya untuk kepentingan volume penjualan itu sendiri. Sehingga hipotesis yang diajukan dalam penelitian ini adalah:

$\mathrm{H}_{3}$ : Diduga Revenue memperkuat pengaruh Receivable Turnover pada kinerja keuangan.

\section{METODE PENELITIAN}

Lokasi perusahaan merupakan faktor yang sangat penting bagi kelangsungan hidup kegiatan suatu perusahaan. Karena letak yang sangat trategis menjadi lebih leluasa dalam 
mengembangkan usahanya. Pabrik madukismo terletak di desa Padokan, Kelurahan Tirtonirmolo, Kecamatan Kasihan, Kabupaten Bantul, Propinsi Daerah Istimewa Yogyakarta. Variabel penelitian adalah subyek yang menjadi titik berat perhatian suatu penelitian. Dalam observasi ini, variabel - variabel yang akan diteliti adalah sebagai berikut:

1. Receivable Turnover

Rasio ini merupakan perbandingan antara penjualan dengan rata-rata piutang, dengan selisih pengukuran prosentase.

2. Inventory Turnover

Rasio ini merupakan perbandingan antara harga pokok penjualan dengan rata-rata persediaan, dengan selisih pengukuran prosentase.

3. Net Profit Margin

Rasio ini digunakan untuk menunjukkan berapa besar persentase pendapatan bersih yang diperoleh dari setiap penjualan, dengan selisih pengukuran prosentase.

4. Kinerja Keuangan

Kinerja keuangan merupakan sesuatu yang dihasilkan oleh suatu perusahaan dalam periode tertentu dengan mengacu pada standar yang ditetapkan, dengan selisih pengukuran prosentase.

5. Moderasi

Moderasi adalah variabel yang mempengaruhi (memperkuat atau memperlemah) hubungan antara variabel independen dengan variabel dependen.

Populasi adalah semua nilai baik hasil perhitungan maupun pengukuran, baik kuantitatif maupun kualitatif, dari pada karakteristik tertentu mengenai sekelompok obyek yang lengkap dan jelas (Nasir 2009). Adapun populasi dalam penelitian ini adalah periode atau waktu dari Pabrik Gula PT.Madukismo Yogyakarta yang berdiri atau beroperasi sampai sekarang yaitu dari tahun 1958 sampai dengan tahun 2014, kurang lebih 56 tahun. Sampel adalah bagian dari populasi. Dengan kata lain sampel adalah bagian dari populasi yang mencerminkan segala karakteristik yang dimiliki oleh keseluruhan populasi. Dari pengertian diatas dapat diambil kesimpulan bahwa sampel adalah sebagian dari keseluruhan obyek amatan yang akan diteliti. Dalam penelitian ini sampel yang diambil adalah 10 tahun, yaitu dari tahun 2004 sampai dengan tahun 2013. Dalam penelitian ini data yang digunakan adalah jenis data kuantitatif. Data kuantitatif adalah data yang dapat dihitung dan diukur secara langsung berupa angka dan nilai. Data kuantitatif ini berupa Laporan Keuangan yaitu Neraca dan Laporan Rugi Dalam penelitian ini sumber data yang digunakan adalah data sekunder, yaitu data yang telah diolah dan diperoleh secara tidak langsung dari sumber dengan mempelajari dokumen yang berhubungan dengan laporan keuangan PT.Madukismo Yogyakarta yaitu Neraca dan Laporan Rugi Laba periode tahun 2004 sampai dengan tahun 2013. Laba periode tahun 2004 sampai dengan tahun 2013 pada PT.Madukismo Yogyakarta tbk.

Persamaan regresi berganda akan dipakai untuk menguji hipotesis yang telah dirumuskan. Pengujian hipotesis dalam penelitian ini menggunakan Analisa Laporan Keuangan dan regresi berganda serta moderasi melalui program SPSS. Model regresi yang pertama menggunakan analisa laporan keuangan tahunan oleh PT.Madukismo Yogyakarta tbk. Model regresi yang kedua menggunakan regresi berganda dengan Receivable Turnover (RT) dan Inventory Turnover (IT) untuk kinerja perusahaan. Model regresi yang ketiga 
menggunakan regresi moderasi, dengan interaksi antar Receivable Turnover (RT) dan Revenue. Teknik ini dimaksudkan untuk memperoleh gambaran tentang Kinerja Keuangan PT.Madukismo Yogyakarta tbk secara keseluruhan. Formulasi rumus untuk regresi berganda sebagai berikut:

$$
Y=a+\beta 1 X 1+\beta 2 X 2+\varepsilon i
$$

Dimana:

$\mathrm{Y}=$ Kinerja Keuangan

$\mathrm{X} 1$ = Receivable Turnover

$\mathrm{X} 2$ = Inventory Turnover

$\varepsilon i$ = Parameter Konstanta

$a=$ Kesalahan Random

Dalam rangka memperbesar volume penjualannya, kebanyakan perusahaan menjual produknya dengan kredit. Penjualan kredit tidak menghasilkan penerimaan kas, namun menimbulkan piutang langganan, dan barulah kemudian pada hari jatuh temponya terjadi aliran kas masuk (cash inflows) yang berasal dari pengumpulan piutang tersebut. Dengan demikian piutang tersebut modal kerja yang selalu dalam keadaan berputar secara terus menerus dalam rantai waktu perputaran modal kerja. Persamaan regresi moderasi akan dipakai untuk menguji hipotesis yang telah dirumuskan, pengujian hipotesis dalam penelitian ini menggunakan analisa laporan keuangan dan regresi moderasi melalui program SPSS. Model regresi pertama menggunakan analisa laporan keuangan tahunan oleh PT.Madukiso Yogyakarta tbk. Model regresi yang kedua menggunakan regresi moderasi dengan interaksi antara Receivable Turnover dan Revenue. Teknik ini dimaksudkan untuk memperoleh gambaran tentang kinerja keuangan PT.Madukismo Yogyakarta tbk secara keseluruhan.

Formulasi rumus untuk regresi moderasi

$$
Y=a+\beta 1 X 1 . M+\varepsilon i
$$

Dimana :

$Y=$ Kinerja Keuangan

$\mathrm{X} 1$ = Receivable Turnover

$M=$ Revenue

$\mathrm{a}=$ Kesalahan Random

$\varepsilon i=$ Parameter Konstanta

Digunakan analisis regresi terhadap dua variabel independen $\mathrm{X} 1 \mathrm{X} 2$, yang diduga berpengaruh positif ataupun negatif terhadap kinerja keuangan PT.Madukismo Yogyakarta tbk. Model analisis yang digunakan penelitian ini secara teoritis akan menghasilkan nilai parameter model penduga yang sahih bila dipakai asumsi klasik.

\section{HASIL PENELITIAN}

PG PS Madukismo (Pabrik Gula Pabrik Spritus Madukismo) adalah satu diantara 17 pabrik yang didirikan oleh Belanda dan berdiri sampai saat ini karena yang lainnya telah dibumi hanguskan oleh Jepang. Pabrik ini satu-satunya yang memproduksi gula dan alkhohol/spirtus. Pabrik ini dibangun pada tahun 1955 oleh Sri Sultan Hamangku Buwono IX. Setelah kurang lebih 3 tahun berdiri baru dilaksanakan peresmian oleh Presiden RI Ir. Soekarno pada tanggal 29 Mei 1958. Dulunya pabrik ini hanya memproduksi gula, tapi mulai tahun 1959 hingga saat ini mengelola gula dan alkhohol/spirtus. Tanggal 14 juni 1955 
memiliki nama P2G MADU BARU PT. saat itu yang memegang saham terbanyak dimilki Sri Sultan Hamangku Buwono IX yaitu 75\%, sedangkan 25\%nya milik pemerintah RI. Saat ini sudah dirubah kepemilikan saham menjadi 65\% milk Sri Sultan Hamagku Buwono X, 35 \% milik pemerintah (dikuasakan pada PT. RAJAWALI NUSANTARA INDONESIA, sebuah BUMN).

Maksud dan tujuan didirikannya pabrik yaitu agar masyarakat Indonesia bisa menikmati hasil pertanian dalam negri tidak hanya produk-produk dari luar. Sehingga pabrik tetap dipertahankan meskipun dulu pernah ada pilihan yang mengakibatkan perusahaan dibawah pimpinan PT. RAJAWALI NUSANTARA. Di atas lokasi bangunan pabrik gula padokan (satu diantara dari 17 pabrik gula Daerah Istimewa Yogyakarta yang dibangun Pemerintah Belanda, tetapi di bumi hanguskan masa pemerintahan jepang), yang terletak di desa Padokan, Kelurahan Tirtonirmolo, Kecamatan Kasihan, Kabupaten Bantul, Propinsi Daerah Istimewa Yogyakarta.

Analisis deskriptif merupakan bagian yang memberikan informasi masing-masing variabel ditinjau dari jumlah sampel yang digunakan, nilai rata-rata (mean), standar deviasi, nilai maksimum, kurtosis dan skewnes (kemencengan distribusi). Berikut ini adalah hasil pengujian statistik deskriptif dari variabel-variabel yang digunakan dalam penelitian ini yaitu receivable turnover dan inventory turnover sebagai variabel bebas (independen) sedangkan NPM sebagai variabel (dependen).

Tabel 1

Hasil Statistik Deskriptif

\begin{tabular}{lccccc}
\hline & N & Minimum & Maximum & Mean & Std.Deviation \\
\hline ReceivableTurnover & 9 & 5.594 & 10.502 & 7.33567 & 1.532529 \\
InventoryTurnover & 9 & .702 & 1.998 & 1.60933 & .410144 \\
NPM & 9 & 15.227 & 88.499 & 37.69922 & 29.259078 \\
ValidN (Iistwise) & 9 & & & & \\
\hline
\end{tabular}

Sumber: Hasil SPSS 19 diolah, 2015 Lampiran 1

Data outlier adalah data yang secara nyata berbeda dengan data-data yang lain. Secara teori uji keberadaan data outlier dapat dilakukan dengan salah satunya yaitu membuat standarisasi data (nilai z). Hasil pengujian data outlier disajikan dalam tabel berikut:

Tabel 2. Hasil Uji Data Outlier

\begin{tabular}{lcc}
\hline ZRecievable Turmover & ZiventoryTurmover & ZNPMI \\
\hline .89371 & .05318 & -.15366 \\
.44612 & -.42314 & .20187 \\
-.14210 & -.15261 & 1.76670 \\
2.08423 & -.28094 & 1.83695 \\
-.91683 & .00694 & -.59379 \\
-40943 & -07052 & -.39236 \\
-.70281 & -16648 & -.65448 \\
-.16228 & -.65437 & -.57046 \\
-1.33323 & 2.54580 & -.98666 \\
-.57624 & -1.33186 & -.45411 \\
\hline Sumber $=$ Hasil SPSS 19 diolah, 2015 lampiran 2
\end{tabular}


Berdasarkan tabel diatas dapat dilihat bahwa terdapat satu data outlier yaitu pada nilai ZinventoryTurnover tahun 2012 sebesar 2.54580, sehingga satu data outlier pada ZinventoryTurnover tersebut harus dihilangkan sedangkan data yang tidak mengalami outlier tidak dihilangkan.

Hasil uji analisis dalam penelitian ini, diperoleh model persamaan regresi sebagai berikut :

Tabel 3. Hasil Uji RT dan IT terhadap NPM

Model Summary

\begin{tabular}{rrrrr}
\hline Model & R & R Square & Adjust R Square & Std. Error of the Estimate \\
\hline 1 & $.615^{\mathrm{a}}$ & .378 & .170 & 26.652465 \\
\hline
\end{tabular}

a. Predictors: (Contant), InventoryTurnover, ReceivableTurnover

Tabel 4

Hasil Uji Simultan

ANOVA $^{b}$

\begin{tabular}{lcrrrrr}
\hline & \multicolumn{1}{c}{ Sum of } & & & & \\
Model & Squares & Df & Mean Square & F & Sig \\
\hline $1 \quad \begin{array}{l}\text { Regression } \\
.241^{\text {a }}\end{array}$ & 2586.626 & 2 & 1293.313 & 1.821 & \\
Residual & 4262.123 & 6 & 710.354 & &
\end{tabular}

Total 6848.749 8

a. Predictors: (Constant), InventoryTurnover, ReceivableTurnover

b. DependentVariable: NPM

Tabel 5 


\section{Coefficients $^{\mathrm{a}}$}

Standardized

Unstandardized Coefficients Coefficients

\begin{tabular}{lccccc}
\cline { 2 - 4 } Model & $\mathrm{B}$ & Std. Error & Beta & $\mathrm{t}$ & Sig. \\
\hline (Constant) & -46.851 & 55.731 & & -.841 & .433 \\
ReceivableTurnover & 11.767 & 6.199 & .616 & 1.898 & .106 \\
InventoryTurnover & -1.098 & 23.162 & -.015 & -.047 & .964 \\
\hline
\end{tabular}

a. Dependent Variabel: NPM

Nilai koefisien regresi X1 (Receivable Turnover) adalah 0,616, ini berarti meningkatnya variabel X1 satu persen maka akan meningkatkan pula variasi nilai Y (NPM) sebesar 0,616 persen atau dapat dikatakan Receivable Turnover memiliki pengaruh positif terhadap NPM. Nilai koefisien regresi X2 (Inventory Turnover) adalah $-0,15$, yang berarti meningkatnya variabel X2 satu persen maka akan menurunkan variasi nilai Y (NPM) sebesar 0,15 persen atau dapat dikatakan Inventory Turnover memiliki pengaruh negatif atau berpengaruh terbalik terhadap NPM.

Analisis data yang digunakan dalam penelitian ini dilakukan menggunakan Moderated Regression Analysis (MRA). MRA adalah salah satu alat khusus dalam pengujian regresi linier berganda, yang dalam persamaan regresinya terkandung unsur interaksi (Ghozali, 2012: 229). Penelitian ini menggunakan model Moderated Regression Analysis (MRA) dengan bantuan komputer program Statistical Package of Social Science (SPSS) versi 19 for window.

Tabel 6. Hasil regresi

\section{Hasil Regresi RT dan RTxM Terhadap NPM}

Model Summary

\begin{tabular}{lrrrr}
\hline Model & R & R Square & Adjust R Square & Std. Error of the Estimate \\
\hline 1 & $.994^{\mathrm{a}}$ & .988 & .984 & 2.456771 \\
\hline
\end{tabular}

a. Predictors (Constant), RTxM, ReceivableTurnover

Tabel 7 
Uji Simultan (F)

ANOVA $^{\text {b }}$

\begin{tabular}{|c|c|c|c|c|c|c|}
\hline \multicolumn{2}{|c|}{ Model } & Sun of Squares & \multirow{2}{*}{$\frac{d f}{2}$} & \multirow{2}{*}{$\begin{array}{r}\text { Mean Square } \\
1458.647\end{array}$} & \multirow{2}{*}{$\frac{F}{241.669}$} & \multirow{2}{*}{$\frac{\text { Sig. }}{.000^{\mathrm{a}}}$} \\
\hline & Regression & 2917.293 & & & & \\
\hline & Residual & & 6 & 6.036 & & \\
\hline & Total & 2953.508 & 8 & & & \\
\hline
\end{tabular}

a. Predictors: (Constant), RTxM, ReceivableTurnover

b. DependentVariabel: NPM

Tabel 8. Koefisien Regresi

Coefficients $^{\mathrm{a}}$

\begin{tabular}{|c|c|c|c|c|c|c|}
\hline & & & & Standardiz & & \\
\hline & Unstand & lardized C & oefficients & Coefficient & & \\
\hline & odel & B & Std. Error & Beta & $\mathrm{t}$ & Sig \\
\hline & (Constant) & 78.890 & 5.260 & & 14.997 & .000 \\
\hline & ReceivableTurnover & r 12.412 & .651 & .990 & 19.059 & .000 \\
\hline & RTxM & .158 & .008 & .983 & 18.925 & .000 \\
\hline
\end{tabular}

a. Dependent Variabel: NPM

Nilai koefisien regresi X1 (Receivable Turnover) adalah 0,990, ini berarti meningkatnya variabel X1 satu persen maka akan meningkatkan pula variasi nilai Y (NPM) sebesar 0,990 persen atau dapat dikatakan Receivable Turnover memiliki pengaruh positif terhadap NPM. Nilai koefisien regresi X2 (RTXM) adalah 0,983, ini berarti meningkatnya variabel X2 satu persen maka akan meningkatkan pula variasi nilai Y (NPM) sebesar 0,983 persen atau dapat dikatakan Moderasi memiliki pengaruh positif terhadap NPM.

\section{PEMBAHASAN}

Hipotesis pertama yang menyatakan bahwa Receivable Turnover tidak ada pengaruh terhadap kinerja keuangan. Hal ini ditunjukkan oleh nilai signifikansi yang lebih besar dari $0,05(0,106>0,05)$. Semakin tinggi tingkat perputaran piutang maka semakin rendah kinerja keuangan pada suatu perusahaan. Dengan demikian kinerja keuangan di industri manufaktur ditentukan oleh perputaran piutang pada industri. Secara langsung perputaran piutang akan mempengaruhi kinerja keuangan pada sebuah perusahaan. Perusahaan yang memberikan jangka waktu kredit yang panjang cenderung memiliki jumlah piutang usaha yang relatif tinggi dibandingkan dengan perusahaan yang memberikan jangka waktu kredit yang pendek. Kas yang diperoleh dari penagihan piutang akan meningkatkan solvensi dan mengurangi resiko kerugian dari piutang tak tertagih. Piutang merupakan aktiva atau kekayaan yang timbul akibat dari dilaksanakannya politik penjualan kredit. 
Politik penjualan kredit ini merupakan politik yang biasanya dipakai dalam dunia usaha untuk memperbesar hasil penjualan. Tetapi dengan politik penjualan kredit ini menimbulkan resiko tidak tertagihnya piutang. Oleh karena itu, manajemen piutang sangat diperlukan agar kebijakan kredit dapat mencapai optimal, yaitu tercapainya keseimbangan antara biaya yang diakibatkan oleh kebijakan kredit dengan manfaat yang diperoleh dari kebijakan tersebut. Penentuan kebijakan kredit yang optimal memerlukan perhitungan yang cermat yang menyangkut tambahan biaya dan tambahan laba pada berbagai kebijakan kredit. Untuk menentukkan kebijakan kredit yang optimal, manajer keuangan harus mempertimbangkan beberapa variabel penting yang berkaitan dengan piutang supaya dapat meminimalisir terjadinya piutang yang tidak dapat ditagih.

Tinggi rendahnya perputaran piutang mempunyai efek yang langsung terhadap besar kecilnya modal yang diinvestasikan dalam piutang. Makin tinggi perputarannya, berarti makin cepat perputaran piutang tersebut, yang berarti makin pendek waktu terikatnya modal dalam piutang. Hipotesis kedua yang menyatakan bahwa Inventory Tunover tidak ada pengaruh terhadap kinerja keuangan. Hal ini ditunjukkan oleh nilai signifikansi yang lebih besar dari 0,05 $(0,964>0,05)$. Semakin tinggi tingkat perputaran persediaan maka semakin tinggi pula kinerja keuangan pada suatu perusahaan. Dengan demikian kinerja keuangan di industri manufaktur ditentukan oleh perputaran persediaan pada industri. Secara langsung perputaran persediaan akan mempengaruhi kinerja keuangan pada sebuah perusahaan. Persediaan adalah elemen modal kerja yang penting bagi perusahaan. Ada tidaknya persediaan menyangkut berlangsungnya operasi perusahaan. Penentuan kebijakan persediaan harus melihat manfaat dan biaya yang timbul akibat perusahaan mempertahankan persediaan tersebut. Oleh karena sangat penting bagi perusahaan untuk menentukkan tingkat persediaan yang optimal. Dengan persediaan yang cukup perusahaan dapat memenuhi pesanan dengan cepat, sehingga penjualan meningkat dan akhirnya keuntungan akan diperoleh perusahaan. Namun sebaliknya persediaan yang terlalu besar membawa konsekuensi timbulnya biaya untuk mempertahankan persediaan tersebut. Persediaan yang terlalu besar akan mengakibatkan perputaran persediaan yang rendah sehingga profitabilitas akan menurun.

Jika dihubungkan dengan keuntungan perusahaan, apabila tingkat perputaran persediaan dalam perusahaan tinggi, maka dapat meningkatkan penjualan, sehingga dapat menaikkan keuntungan yang diperoleh perusahaan. Sebaliknya bila perputaran persediaan rendah menyebabkan besarnya biaya penyimpanan digudang, turunnya kualitas dan keusangan persediaan akan memperkecil keuntungan perusahaan. Oleh karena itu, cepat lambatnya perputaran persediaan sangat menentukkan besar kecilnya keuntungan yang diperoleh perusahaan. Hipotesis ketiga yang menyatakan bahwa Revenue mampu menguatkan hubungan antara Receivable Turnover terhadap kinerja keuangan di industri manufaktur. Hal ini ditunjukkan oleh nilai signifikansi yang lebih kecil dari 0,05 $(0,000<$ $0,05)$.

Semakin tinggi tingkat perputaran piutang maka semakin rendah kinerja keuangan pada suatu perusahaan. Makin tinggi rasio (turnover) menunjukkan modal kerja yang ditanamkan dalam piutang rendah, sebaliknya kalau rasio semakin rendah berari ada over investment dalam piutang sehingga memerlukan analisa lebih lanjut, mungkin karena bagian kredit dan penagihan bekerja tidak efektif atau mungkin ada perubahan dalam 
kebijaksanaan dalam pemberian kredit. Volume penjualan adalah tingkat penjualan yang diperoleh perusahaan untuk periode tertentu dalam satuan (unit/total/rupiah). Bagi setiap perusahaan tujuan yang hendak dicapai adalah memaksimumkan profit disamping perusahaan ingin tetap berkembang. Realisasi dari pada tujuan ini adalah melalui volume penjualan yang mantap karena masalah penjualan merupakan kunci dari sukses tidaknya suatu perusahaan.

Dalam kegiatan marketing kenaikan volume penjualan merupakan ukuran efisiensi, meskipun tidak setiap kenaikan volume penjualan diikuti dengan kenaikan laba. Volume penjualan merupakan jumlah total yang dihasilkan dari kegiatan penjualan barang. Semakin besar jumlah penjualan yang dihasilkan oleh perusahaan, semakin besar kemungkinan laba yang akan dihasilkan perusahaan. Oleh karena itu volume penjualan merupakan salah satu hal penting yang harus dievaluasi untuk kemungkinan perusahaan agar tidak rugi. Jadi volume penjualan yang menguntungkan harus menjadi tujuan utama perusahaan dan bukannya untuk kepentingan volume penjualan itu sendiri.

\section{KESIMPULAN}

Berdasarkan hasil analisis data yang telah dilakukan dalam penelitian ini, diperoleh kesimpulan sebagai berikut:

a. Pada uji hipotesis pertama dalam penelitian ini membuktikan bahwa Receivable Turnover tidak berpengaruh signifikan terhadap kinerja keuangan, yang ditunjukkan oleh nilai signifikan sebesar $(0,106>0,05)$.

b. Pada uji hipotesis kedua dalam penelitian ini membuktikan bahwa Inventory Turnover tidak berpengaruh signifikan terhadap kinerja keuangan, yang ditunjukkan oleh nilai signifikan sebesar $(0,964>0,05)$.

c. Pada uji hipotesis ketiga dalam penelitian ini membuktikan bahwa Revenue sebagai variabel moderasi memperkuat pengaruh Receivable Turnover terhadap kinerja keuangan, yang ditunjukkan oleh nilai signifikan sebesar $(0,000<0,05)$.

\section{SARAN PENELITIAN}

Dalam meningkatkan produktifitas usahanya maka PT.Maduksimo harus bisa mengoptimalkan usaha yang dijalankan pada saat ini agar tercapai tingkat profitabilitas yang optimal sehingga akan dapat juga meningkatkan kesejahteraan bagi para anggotanya. PT.Madukismo dalam meningkatkan kehidupan dan taraf hidup anggotanya khususnya dan masyarakat pada umumnya dengan lebih mengembangkan dan memperluas kegiatan usahanya. PT.Madukismo hendaknya menggunakan kinerja keuangan dengan seefisien mungkin agar tidak ada kinerja yang tidak digunakan sehingga perputaran kinerja keuangan menjadi bertambah cepat agar perusahaan semakin efisien dalam menjalankan usahanya.

\section{DAFTAR PUSTAKA}

Vishal Gaur, Marshall L. Fisher, Ananth Raman. 2004. An Econometric Analysis of Inventory Turnover Performance in Retail Services. New York University, vol. 8, No.72, Hal. 44. West 4 th st., New York, NY 10012, Ph: 212 998-0297, Fax: 212 995-4227.

Akhmad Syafrudin Noor. 2011. Analisis Faktor-Faktor yang Mempengaruhi Kinerja Keuangan Perusahaan Telekomunikasi yang Go Public di Bursa Efek Indonesia. Jurnal 
Manajemen dan Akuntansi. Vol. 12, No. 1, Hal. 13, April 2011. Universitas Antakusuma Pangkalan Bun Jl. Iskandar No. 63 Pangkalan Bun.

Welas. 2004. Analisis Kinerja Keuangan dengan Pendekatan Sistem Du Pont (Studi Empirik pada Perusahaan Rokok yang sudah Go Public Periode tahun 2000-2004). Hal. 58. Fakultas Ekonomi Universitas Budi Luhur Jakarta Jl. Raya Ciledug, Petukangan Utara, Kebayoran Lama, Jakarta 12260.

Abdel - Rahman Kh. El - Dalabeeh. 2013. The Role of Financial Analysis Ratio in Evaluating Performance (Case Study: National Chlorine industry). Journal of Contemporary Research in Business. Vol. 5, No. 2, Hal. 13, June 2013. Accounting Department, Faculty of Finance and Business Administration, AL al-bayt University, Mafraq, Jordan.

Maya Imaniar DR. 2009. Peran Moderasi Intensitas Kompetisi Pasar pada Penggunaan Informasi Sistem Akuntansi Manajemen Terhadap Kinerja Unit Bisnis dan Kepuasan Kerja. Jurnal Akuntansi dan Auditing. Vol. 5, No. 2, Hal. 181, Mei 2009 : $181-196$. Universitas Diponegoro.

Hasan Ayaydin, Ibrahim Karaaslan. 2014. The Effect of Research and Development Invesment on Firms' Financial Performance : Evidence Manufacturing Firms In Turkey. Journal Economy \& Management in Valetta. Vol. 9, No. 1, Hal. 23, November 2014.

Ms. Shikha Gupta. 2014. An Empirical Study of Financial Performance of Icici Bank - A Comparative Analysis. Journal of Business Studies (JBS). Vol. 1, Issue 1, 2014. Assistant Professor (Finance \& Marketing), Institute of Innovation in Technology and Management, Janakpuri. New Delhi.

Choi Sang Long, Mahanra Rao a/I Gondyah, Ajagbe Akintunde Musibau. 2013. Can Employee Share Improve Firm's Performance ? A Malaysian Case Study. Journal Information Management and Business Review. Vol. 5, No. 3, Mar 2013 (ISSN 22203796). University Teknologi Malaysia (UTM), Malaysia Wawasan Open University, Malaysia.

Ali Setiawan. 2008. Analisis Pengaruh Manajemen Piutang dan Persediaan Terhadap Profitabilitas Perusahaan Manufaktur yang Listing di Jakarta Islamic Index Tahun 2001 - 2006. Vol. 1, No. 5, januari 2008. Universitas Islam Negri Sunan Kalijaga Yogyakarta.

Zhao Hai Chen. 2013. A Case - based Analytical Study on the Strategic Evaluation of Common Equity Performance of SIA in a Global Organic Environment. Journal of Contemporary Management. Vol. 1, No. 1, Hal. 51, Agust 2013. Oxford Brookes University, UK (BSc. Hons) ACCA, UK (Affiliate) ISCA, Singapore (Associate) 701-G62, WenJingLi BinYouRd HeXi Dis TianJin, 300060, China.

Hsin-Hui I. H. Whited, Hailu Regassa. 2005. Forecasting an Income Statement and Balance Sheet. Journal of Business Cases and Applications. Hal. 1, Colorado State University - Pueblo.

Enekwe Chinedu Innocent, Okwo Ifeoma Mary, Ordu Monday Matthew. 2013. Financial Ratio Analysis As a Determinant of Profitability in Nigerian Pharmaceutical Industry. International Journal of Business and Management. Vol. 8, No. 8; 2013, Hal. 107. March 2013. www.ccsenet.org/ijbm. 
Aleksandar Grubor, Nikola Milicevic, Kristina Mijic. 2013. Empirical Analysis of Inventory Turnover Ratio in FMCG Retail Sector - Evidence from the Republic of Serbia. Journal Inzinerine Ekonomika-Engineering Economics. Vol. 5, No. 24, Hal. 401, mei 2013. University of Novi Sad. Http://dx.doi.org.

J. E. (Joe) Barth. 2011. A model for wine list and wine inventory yield management. International Journal of Hospitality Management. No. 30, Hal. 701, 2011. University of Guelph.

Hemanta Saikia. 2012. Measuring Financial Performance of Small Scale Industries: Some Evidences from India. Journal of Applied Economics and Business Research. Vol. 2, No. 1, jan 2012 